\title{
Road Tripping across North America: A Medical Student's Perspective Trip
}

\author{
Jonathan Robert Whelan \\ Faculty of Medicine, University of Ottawa, Ottawa, Ontario, Canada
}

ABSTRACT

This explorative report provides an overview of the experiences and insights of a Canadian medical student's seven-week, solo road trip across the United States and Canada. Enriched with stories of acute musculoskeletal injuries, close calls on the road, locksmith services and small-town celebrations, travel moments and mishaps are used to guide readers into personal insights. This distinctive narrative enables the inspection of meaningful themes which include emotional resiliency in medicine, rural emergency healthcare, personal relationships and travel privilege.

RÉSUMÉ

Ce rapport offre un aperçu des expériences et des idées tirées d'un voyage en solo de sept semaines, mené par un étudiant en médecine canadien à travers les États-Unis et le Canada. Enrichis d'histoires de blessures musculo-squelettiques aiguës, d'incidents de la route évités de justesse, de services de serruriers et de célébrations dans des petites villes, ces moments du voyage et les incidents sont utilisés afin d'inciter les lecteurs à refléter sur leurs propres perspectives personnelles. Ce récit distinct permet d'apprécier certains thèmes y inclus la résilience émotionnelle en médecine, les soins de santé d'urgence en milieu rural, les relations personnelles ainsi que le voyage en tant que privilège.

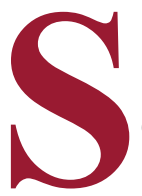

purred by the prospect of one final summer break, I decided to pursue photography and driving growth for the summer of 2019. This entailed putting aside all medical endeavors after the end of pre-clerkship on May 31 st and committing to a solo United States-Canada road trip. Armed with hours of podcasts and Elton John's Greatest Hits, I took off from my hometown of Rothesay, New Brunswick on June 19th. With a rough travel itinerary, I stayed with family and friends in larger cities (e.g. Toronto, Chicago, San Francisco, Vancouver, Calgary), camped in protected parks (e.g., in Colorado, Utah, California, Alberta, Saskatchewan, Manitoba, Ontario) and boarded in cheap Airbnb accommodations (e.g., Lincoln, Denver, Las Vegas, Portland).

My seven-week road trip consisted of twelve U.S. states, seven Canadian provinces, twelve Na-tional Parks and thirty-seven gas tank fill-ups. The trip further included a total driving distance of 16719 kilometers which is equivalent to the direct distance between Melbourne, Australia and Ottawa, a walking distance of 522 kilometers on the iPhone Health App, one near-collision with a moose in Northwestern Ontario, one lost set of car keys and correspondingly the services of one Utah locksmith. It should be noted that one detail not included above was the elevated blood pressure of my mother during the weeks I was gone.
When I returned to Ottawa on August 5th, one of my friends asserted that "trips and travel allow us to grow in ways we could only have dreamed about." Being alone for most of the trip, I learned a lot about myself and my overall temperament. Even though I am not a life guru, as exemplified by past medical school rejections for lack of life experience, these are some of the lessons that I took away from my travels. So, prepare the imaginary campfire and smores because here we go.

\section{Appreciating the Small Moments with People}

While on the road, I largely felt comfortable being alone and pursuing my own self-interests. However, it was very gratifying when I used my small moments with strangers to create new conversations and the space for positive experiences. In this way, I had connecting moments with travelers and locals alike. From these interactions, it dawned on me that you interact with people for variable amounts of time in life. You may interact with some individuals for a brief second or minute within a café, gas station, hospital corridor or grocery store. With some individuals, your interaction may be extensive on the order of months and/or years (e.g., friends, colleagues, etc.). Irrespective of the length of interaction, all individuals deserve to be treated with the same dignity and respect. Equally to this point is expressing respect for our patients. Regardless of the clinical context, the length of clinical interaction or the patient's demographics (e.g., sex, race, socioeconomic status,

Keywords: person, wellness, humanities, resiliency, compassionate Care, healthcare sustainability, cimmunication 
geographic location), we must provide respect, humility, professionalism and empathy to all our patients.

\section{Things Will Not Always Go as Planned}

In medicine, like the broader sense of life, things will not always go as planned or predicted (1). Despite the best medical care, procedures will elicit unexpected complications, patients will become suddenly unstable on the medical floor and patients will not always make full recoveries from diseases $(2,3)$. Under these stressful circumstances, medical professionals must demonstrate flexibility, perseverance and emotional regulation in their care for patients (4). Incurring my own unanticipated situations on the road trip, I developed awareness of my emotional responses in stressful moments and the ways in which I can improve upon these shortcomings.

Before hitting the open highway, I prayed that my Honda Fit would hold up the entirety of the trip and that my essential valuables would not be misplaced (e.g., passport, phone, wallet, keys). Despite these high hopes, I did not foresee the following moments occurring on my trip:

1. I would have a near head-on collision with a moose on the highways of Northwestern Ontario between Winnipeg and Thunder Bay at midday.

2. I would lose my only set of car keys in the Virgin River of Zion National Park over the fourth of July weekend and totally ruin my mother's Sunday in the process.

3. Owing to an unmarked road condition change to gravel, I would scramble to prevent a rollover and control my car's severe fishtailing on a local Saskatchewan highway.

I reacted in a multitude of ways in these stressful moments: hopelessness and despair with the loss of my car keys, frustration with the unmarked Saskatchewan highways and anger with the unlikely moose encounter.

In high acuity medical situations, health professionals must obtain and interpret pertinent medical information to weigh treatment options for benefits and risks (5). Since emotional regulation can improve patient care in these stressful situations, the regulation of reactive emotions and the adoption of resilient emotions such as calmness, acceptance and resolve are necessary (6). Even though I was able to overcome these stressful travel situations, I did not effectively manage and suppress my undesired emotions in these moments. Reflecting in this manner, I must continue to work on the adaptation of my emotions under stress. Ultimately, stressful situations are inherent in medicine, thus, to effectively manage and process these situations, one must achieve emotional regulation.
Rural Emergency Healthcare

There were many moments on my road trip when the landscape had me shaking my head in amazement and completely speechless. These included the Rocky Mountains of Colorado, the rock formations of Utah, the massive Redwood trees of California, the seaside cliffs of the West Coast and the glacier water of Alberta. I gained a greater appreciation for the beauty of North America after seeing these spectacular natural wonders. Additionally, I also gained a greater understanding of the expansive rural North American land.

Although consensus varies on the exact numbers, rurality is defined as areas with minimal population size and density (7). With roughly $95 \%$ of North America's landmass considered rural, I drove through rural towns across the Plains, Prairies, Rocky Mountains and Northwestern Ontario $(7,8)$. I must admit I fell in love with one rural town in Utah named Hanksville (population 220) after enjoying their ten-minute July 4th parade and straws of Pixy Stix candy.

These rural towns and their access to medical services were on the forefront of my thoughts when I visited San Francisco though. My friend dislocated her shoulder rock-climbing and was able to receive medical treatment at a nearby walk-in clinic within twenty minutes. This access to acute healthcare services would not have been as timely in the rural towns I visited as the majority of rural residents have to travel up to 120 kilometers to access a physician or nurse practitioner (9). This barrier leads to longer onset-to-imaging and onset-totreatment times for rural patients in acute clinical situations compared to urban patients $(10,11)$. Consequently, rural patients have greater morbidity and mortality rates from these longer pre-hospital times (12).

Innovative approaches are needed to negate the inequitable access to emergency healthcare services and technology for rural patients. Greater investment into paramedic services in rural areas would improve ambulance networks, coordinate quicker ground transfers and increase the provision of advanced care on scene (13). Since rural emergency departments provide care on average to 15,000 patients a year, medical supplies and equipment should be standardized on patient volume and appropriately allocated across rural emergency departments $(13,14)$. Lastly, with rural emergency departments often distanced 150 kilometers from tertiary care centers, well-organized systems of inter-facility transfer and reception are needed for patient transports. This includes organized transport teams, early activation and mobilization pathways for the transport system and improved 
multihospital communication upon transport activation $(14,15)$. Fundamentally, these efforts will enable the provision of more equitable and improved emergency care for rural patients.

\section{Valuing Time with Family and Friends}

In a few of the bigger cities, I was able to trade in my camping gear to stay with friends and family members (e.g., former McGill classmates, my uncle and my sister). It was great to catch up with these loved ones over fun outdoor activities. However, I always felt sad saying goodbye and continuing my road trip because some of these individuals I had not seen or talked to in years. I typically wished I could have a few more days to continue reconnecting by delaying my future reservations. Reflecting on this now, I am extremely grateful and honored to have such people in my life that make me feel this way. These relationships give me a strong network of support in addition to my family and classmates closer in proximity to Ottawa. These relationships will be critical for my well-being and mental health during the strenuous hours of clerkship as they will be relied on during fourth-year medical electives. Beyond medical school, these relationships will foster psychosocial support to mitigate my work-related stress and prevent professional burnout (16). With that said, we must not forget to maintain and nurture the social relationships in life. Even though exhaustion might set in with work-related stress, interacting with family and friends will facilitate greater emotional satisfaction and reduce job isolation (17). It could be as simple as keeping friends and family updated with life activities.

\section{Conclusion}

When discussing this trip with my physician mentor, she remarked that this adventure was so important for me to experience "in order to have more empathy" for my patients. This resonated with me because my trip increased my selfawareness of my position in society. I am privileged to have been able to pursue such a trip. Many people are not able to travel in their lifetime due to significant financial insecurities, safety concerns, limiting health illnesses or family obligations. Given this new perspective, I now ask patients in a gentler way if they have recently traveled for my medical histories. I also reassure the patient it is okay to say "no" or I urge them we will strive towards travel in the future.

With that final reflection, that is the completion of my commentary as I hope it connected with you in a personal way! Of course, if you ever need playlist or podcast recommendations, you know who to ask. From my hours of solitude and unpredictable moments on the road trip, I was able to nurture greater emotional and leadership skills. I hope these advances will make me a better colleague and caregiver for my all future co-workers and patients.

\section{REFERENCES}

1. Hall M, Hall, S. When Treatment Becomes Trauma: Defining, Preventing, and Transforming Medical Trauma [Internet]. VISTAS Online. 2013;73: 1-15 [cited 2019 Sep 20]. Available from: https://www.counseling.org/docs/ default-source/vistas/when-treatment-becomes-trauma-defining-preventing-.pdf

2. Healey M, Shackford S, Osler T, Rogers F, Burns, E. Complications in Surgical Patients. Archives of Surgery. 2002;137(5):611-8.

3. Field $M$, Cassel C. Approaching death: improving care at the end of life. Washington, D.C.: National Academy Press; 1997.

4. Lauria M, Gallo I, Rush S, Brooks J, Spiegel R, Weingart S. Psychological Skills to Improve Emergency Care Providers' Performance Under Stress. Annals of Emergency Medicine. 2017;70(6):884-90

5. Gupta M, Upshur R. Critical thinking in clinical medicine: what is it? Journal of Evaluation in Clinical Practice. 2012;18(5):938-44.

6. Harvey A, Nathens A, Bandiera G, Leblanc V. Threat and challenge: cognitive appraisal and stress responses in simulated trauma resuscitations. Medical Education. 2010;44(6):587-94.

7. Housing Assistance Council. Rural Research Brief - Rurality in the United States [Internet]. 2011 [cited 2019 Sep 23]. Available from: http://www.ruralhome.org/storage/research_notes/Rural_Research_Note_Rurality_web. pdf

8. Moazzami, B. Strengthening Rural Canada: Fewer \& Older: Population and Demographic Challenges Across Rural Canada [Internet]. 2015 [cited 2019 Sep 23]. Available from: http://strengtheningruralcanada.ca/file/FewerOlder-Population-and-Demographic-Challenges-Across-Rural-Canada. pdf

9. Luu J, Kirychuk S, Karunanayake C, Lawson J, Pahwa P, Rennie D, et al. Access To Routine Medical Care And Cardiovascular Disease Outcomes In A Rural Canadian Population. Canadian Journal of Cardiology. 2017;33(10):S113-4.

10. Koifman J, Hall R, Li S, Stamplecoski M, Fang J, Saltman A, et al. The association between rural residence and stroke care and outcomes. Journal of the Neurological Sciences. 2016;363:16-20.

11. Hassan A, Pearce N, Mathers J, Veugelers P, Hirsch G, Cox J. The effect of place of residence on access to invasive cardiac services following acute myocardial infarction. Canadian Journal of Cardiology. 2009;25(4):207-12.

12. DesMeules M, Pong R. How Healthy are Rural Canadians? An Assessment of their Health Status and Health Determinants [Internet]. 2006 [cited 2019 Sep 23]. Available from https://secure.cihi.ca/free_products/rural_canadians_2006_report_e.pdf

13. Wilkinson T, Bluman B. Rural Emergency Medicine Needs Assessment British Columbia, Canada - 2014-2015 - Final Report [Internet]. 2015 [cited 2019 Sep 23]. Available from https://ubccpd.ca/sites/ubccpd.ca/ files/2015-Report-Rural-EM-Needs-Assessment.pdf

14. Fleet R, Dupuis G, Fortin J-P, Gravel J, Ouimet M, Poitras J, et al. Rural emergency care $360^{\circ}$ : mobilising healthcare professionals, decision-makers, patients and citizens to improve rural emergency care in the province of Quebec, Canada. International Journal of Integrated Care. 2019;19(4):535

15. Leira E, Hess D, Torner J, Adams H. Rural-Urban Differences in Acute Stroke Management Practices. Archives of Neurology. 2008;65(7): 887-91.

16. Rogers E, Polonijo A, Carpiano R. Getting by with a little help from friends and colleagues: Testing how residents' social support networks affect loneliness and burnout. Can Fam Physician. 2016; 62(11):e677-83.

17. Rutherford $\mathrm{K}$, Oda J. Family medicine residency training and burnout: a qualitative study. CMEJ. 2014;5(1):e13-23. 